\title{
Field and Laboratory Studies of Solarcum Hand Operated Hybrid Knapsack Sprayer
}

\author{
Shubham R. Zilpilwar, Surendra R. Kalbande, Manisha V. Gahane and Neha Daharwal \\ College of Agriculture Engineering and Technology Dr. Panjabrao Deshmukh Krishi \\ Vidyapeeth Akola, Maharashtra-444104, India \\ *Corresponding author
}

\begin{tabular}{|l|}
\hline K e y w o r d s \\
$\begin{array}{l}\text { Knapsack sprayer, } \\
\text { Performance of SPV } \\
\text { module, Flow rate, } \\
\text { Laboratory test, Field test, } \\
\text { Nozzles, Okra and Bitter } \\
\text { guard }\end{array}$ \\
\hline Article Info \\
\hline $\begin{array}{l}\text { Accepted: } \\
\text { 24 February } 2018 \\
\text { Available Online: } \\
\text { 10 March } 2018\end{array}$ \\
\hline
\end{tabular}

A B S T R A C T

Traditionally the hand lever operated knapsack sprayer was used by the Indian farmers for spraying of pesticide, weedicide, fungicides, liquid chemicals etc. however it involves fatigue due to continuous hand lever operation results in the low efficiency. Now a days the power operated knapsack sprayers available in the market are being used for spraying operation in production agriculture but it is associated with more vibrations, noise levels causes the high level of fatigue during the operation hence labors are reluctant to use this types of sprayer. Also in the remote area due to unavailability of fuel and electricity there were lot of problems occurred in the agricultural operation. In order to overcome these problems solar cum hand operated Knapsack Sprayer was designed by using modern development techniques. Under this study performance evaluation was carried out in laboratory as per the Indian standard using different test rigs in testing center and field tests were carried out on different crops such as Okra and Bitter guard in the field. The field efficiency of using SPV, battery cum hand operated knapsack sprayer and Hand lever operated knapsack sprayer was 89.42 and 80.39 per cent, respectively and the solution required for spraying one ha field were found to be 498 litres and 512 litres, respectively. SPV, battery cum hand operated knapsack sprayer has two times greater field capacity than hand operated knapsack sprayer.

\section{Introduction}

Spraying is one of the most important operations in crop production. The need of chemical application arises from man's desire to protect his crop from attack of various pests and diseases. Spraying operation is a complex process and can be influenced by many variables. The magnitude and uniformity of spray deposition depend on the canopy geometry, pesticide properties; spray equipment design, application parameters and weather conditions (Thread Gill and Smith, 1975).

"Energy - demand" is one of the major threads for our country. Finding solutions, to meet the "energy demand" is the great challenge for social scientist, engineers, entrepreneurs and industrialist of our country. According to them, applications of non-conventional energy are the only alternate solution for conventional energy demand. SPV cum Hand operated hybrid knapsack sprayer can use in remote 
areas by using solar energy, when solar and electrical energy not available hand operated lever can be used for spraying operation without creating pollution and noise. This type of sprayer makes spraying operation ecofriendly.

\section{Materials and Methods}

This deals with the performance evaluation of Solar cum hand operated hybrid knapsack sprayer in laboratory and field. The methodology used for research work is discussed in following sections.

Performance of SPV module at different atmospheric condition

For study of V-I characteristics of module, it was placed on flat surface in sunshine hours from $9.00 \mathrm{am}$ to $5.00 \mathrm{pm}$. When solar radiation incident on module electric current is generated. Charge controller was used to control the charging and prevents from reverse flow of current. A multimeter was used to measure the current and voltage in the circuit.

Solar intensity was measured by pyranometer, wind velocity measured by anemometer, panel temperature measured by IR thermometer and ambient temperature measured by mercury thermometer.

The observation of $\mathrm{V}_{\mathrm{m}}, \mathrm{I}_{\mathrm{m}}$ of solar panel was recorded at different condition and the power was determined by using the equation.

$\mathrm{P}_{\mathrm{m}}=\mathrm{I}_{\mathrm{m}} \times \mathrm{V}_{\mathrm{m}}(1)$

Where, $\mathrm{P}_{\mathrm{m}}=$ Power, $\mathrm{W} \mathrm{I}_{\mathrm{m}}=$ current, $\mathrm{A} \mathrm{V}_{\mathrm{m}}=$ Voltage, $\mathrm{V}$

\section{Efficiency of SPV module}

The efficiency of the solar panel was determined by the following equation.
$\eta=\frac{\operatorname{Vm} \times \operatorname{Im}}{\mathrm{I} \times S} \times 100$

Where,

$V m$ - Maximum voltage, $\mathrm{V}^{\mathrm{Im}}-$ Maximum current, A,

$\mathrm{I}$ - intensity of radiation, $\mathrm{W} / \mathrm{m}^{2} \mathrm{~S}-$ Area of the cell, $\mathrm{m}^{2}$

Fill factor of solar cells can be calculated by using the following relation;

F.F. $={ }^{\frac{(\text { Vm } x \text { Im })}{(V o c \times I s c)}}(3)$

Where, $\mathrm{V}_{\mathrm{oc}}$ - open circuit voltage, $\mathrm{V}, \mathrm{I}_{\mathrm{sc}}-$ short circuit current, A

Therefore, the maximum power output, $\mathrm{Pm}$ in Watts can be calculated as:

$\mathrm{Pm}=\mathrm{V}_{\mathrm{m}} \times \mathrm{I}_{\mathrm{m}}=\mathrm{V}_{\mathrm{oc}} \times \mathrm{I}_{\mathrm{sc}}$

Performance evaluation of SPV, battery cum hand operated knapsack sprayer

\section{Laboratory test}

Test for discharge rate (free flow)

Test for endurance of pump

Test for endurance of spray nozzle

Spray distribution patternator test

Test for components

\section{Test for discharge rate (free flow)}

The sprayer tank was filled with cleaned water and suction and delivery hose were inserted in to the tank so that water sucked from suction pipe will receive back in tank through delivery hose inserted in to tank. The pump pressure is set up to $300 \mathrm{kPa}$ for the test on the basis guidelines given in the IS 10134:1994. Each test was carried out for a period of 1 minute. 
The discharge collected from the reservoir and measured with the help of measuring jar. View of discharge measurement is shown in figure 1 .

\section{Test for endurance of pump}

The endurance test of pump was carried in laboratory. The sprayer tank was filled with cleaned water and suction and delivery hose were inserted in to the tank so that water sucked from suction pipe will receive back in tank through delivery hose inserted in to tank. The pump pressure $300 \mathrm{kPa}$ was selected for the test on the basis of manufactures recommended pressure. This test was carried out for a period of $48 \mathrm{hrs}$. The discharge collected from the reservoir in interval of $6 \mathrm{~h}$ and measured with the help of measuring jar. This test was carried out as per IS 10134:1994.

\section{Test for endurance of spray nozzle}

The endurance test of pump was carried in laboratory. The sprayers tank was filled with cleaned water and suction and delivery hose were inserted in to the tank so that water sucked from suction pipe will receive back in tank through delivery hose inserted in to tank. The pump pressure $300 \mathrm{kPa}$ was selected for the test on the basis of manufactures recommended pressure. This test was carried out for a period of $48 \mathrm{hrs}$. The discharge collected from the reservoir in interval of $6 \mathrm{~h}$ measured with the help of measuring jar. This test was carried out as per IS 10134:1994.

\section{Spray distribution patternator test}

The nozzle spray pattern was measured by using the patternator test rig. The pressure was set as per the requirement Sprayer. The test was carried out on pressure of $300 \mathrm{kPa}$ for different nozzles. Each trial on set pressure was recorded in three replications and the average reading graph was plotted on the basis of liquid collated in the tubes. The patternator normally consists of 16 channels each $25 \pm$ $0.25 \mathrm{~mm}$ wide and of any convenient length provided that it in compasses the area of the spray. While spray pattern calibration the measuring tubes were placed below the each channel where the spray swath reached. Then collect the samples and plot the graph to show the pattern of spray across the swath width. View of spray distribution patternator test and cone angle measurement is shown in figure 2.

\section{Measurement of nozzle cone angle}

The nozzle cone angle was measured by using the nozzle performance test rig. The pressure was set as per the requirement i.e. $300 \mathrm{kPa}$. Trial on set pressure was recorded in three replications. The observed tests results are recorded. For this purpose following methodology was used:

For measurement of nozzle cone angle, the test was carried at a place protected from draughts. The nozzle was mounted on the test rig and connected to a supply of clean water to measure the pressure. The pressure gauge of $700 \mathrm{kPa}$ was selected which is in the range of specified Indian Standard.

The spray was started at a controlled pressure of $300 \mathrm{kPa}$ within a fluctuation of \pm 10 percent. The arm on the protector was adjusted in the test rig so as to coincide with the clearly visible straight boundary lines of the nozzle spray pattern. The spray angle was observed on the protector and rounded off in whole degrees.

\section{Test for components}

\section{Test for hose and hose connection}

Following methodology is used for test for hose and hose connection as per IS 10134:1994: 
The inlet of the hose connected to a hydraulic pump through hose connection. The other end of the hose connected to the appropriate cutoff device.

The cut-off device kept closed that, no discharge allowed.

A minimum hydrostatic pressure of $1.52 \mathrm{MPa}$ using water as liquid, developed in the hose assembly and pressure was retained for $1 \mathrm{~min}$.

Leakage, crack or breakage during the test was observed.

\section{Test for strap and its assembly}

Following methodology is used for test for strap and its assembly as per IS 10134:1994:

Tank filled with water to its specified capacity.

The sprayer without discharge line hung from solid support by its strap simulating its carriage on the shoulder of an operator.

Raised the tank vertically to a height of $300 \mathrm{~mm}$ and allowed to drop freely and hang by the strap.

Repeated the above operation for 24 times and observed the breakage in straps, brackets etc. test setup for strap and its assembly is shown in figure 3.

Test for operating lever, handle and piston rod

Following methodology is used for test for operating lever, handle and piston rod as per IS 10134:1994: Discharge outlet of the spray closed, that is, no discharge allowed from the sprayer and handle operated to develop the pressure in the sprayer until a pressure of minimum two and a half times the normal working pressure is developed (Incase pressure will not develop use external source of pressure). Observed the crack or break in handle, operating lever and piston rod during test.

\section{Field test}

\section{Speed of operator}

For calculating travelling speed two poles $15 \mathrm{~m}$ apart was placed approximately in middle of the test run. On the opposite side also two poles were placed in similar position, $15 \mathrm{~m}$ apart so that four poles forms corners of rectangle, parallel on long side of the plot. The speed was calculated from the time required for operator to travel the distance $(15 \mathrm{~m})$ between two poles. Average of such reading was taken to calculate the speed of operator. The forward speed of operation was calculated by observing the distance travelled and time taken and calculated by following formula (Mehta et al., 2005).

$$
\mathbf{S}=\frac{\mathbf{L}}{\mathbf{T}_{(4)}}
$$

Where, $\mathrm{S}=$ speed of operation, $(\mathrm{m} / \mathrm{s}) \mathrm{L}=$ distance travelled, $\mathrm{m} \mathrm{t}=$ time taken.

\section{Theoretical field capacity}

For calculating the theoretical filed capacity, working width of spray nozzle and travelling speed has been taken in to consideration. It is always greater than the actual field capacity. Theoretical field capacity is calculated by using following formula (Mehta et al., 2005).

T. F. C. $=\frac{\mathbf{S} \times \mathbf{W}}{10}$

Where,

T.F.C. $=$ theoretical field capacity, $(\mathrm{ha} / \mathrm{h})$ 
$\mathrm{W}=$ theoretical width of Spray nozzle, $(\mathrm{m})$

$\mathrm{S}=$ speed of operation, $(\mathrm{km} / \mathrm{h})$

\section{Effective field capacity}

For calculating effective field capacity, the time consumed for actual work and lost for other activities such as turning and filling the tank of spray.

Effective field capacity was calculated by following formula (Mehta, et al., 2005).

E. F. C. $=\frac{A}{T_{P}+T_{1}}(6)$

Where, E.F.C. $=$ effective field capacity $(\mathrm{ha} / \mathrm{h})$ $\mathrm{A}=$ area (ha) $\mathrm{Tp}=$ productive time $(\mathrm{h}) \mathrm{T}_{1}=$ non-productive time, (h)

\section{Field efficiency}

Field efficiency will be calculated by taking ratio of effective field capacity to theoretical field capacity. It is always expressed in percentage. It was calculated by following formula (Mehta et al., 2005).

Field efficiency $(\%)=\stackrel{\text { E.F.C. }}{=\text { T.F.C. }} \times 100(7)$

Where, E.F.C. $=$ effective field capacity $($ ha/h) T.F.C. $=$ theoretical field capacity $(\mathrm{ha} / \mathrm{h})$

The field test was carried out in following steps:

The Spray tank was filled up with liquid. The tank was mounted at the back. The solar system is switch on and the liquid was sprayed using the pressure of the pump (Fig. 4 and 5).

The effective performance of the developed solar, battery and hand operated knapsack sprayer was determined by practical trials in the field.
The field was made in an open field measuring of $31 \mathrm{~m}$ by $15 \mathrm{~m}$. The operator walked within a space of $0.7 \mathrm{~m} / \mathrm{s}$ through the test field. The discharge volume in litre per minute was recorded.

The procedure was replicated four times and the mean value was determined.

Above same procedure was followed by Hand operated lever and recorded all above parameters.

Comparative study of spraying operation by Developed SPV cum hand operated hybrid knapsack sprayer and hand operated knapsack sprayer was carried out in laboratory and field.

\section{Calibration of sprayer}

Sprayer was calibrated as below

Area of Test plot $=$ Length $\times$ Width $(8)$

Application Rate $=\frac{\text { Volume rate }\left(\frac{\mathrm{dit}}{\mathrm{h}}\right)}{\text { Area rate of sprayer }\left(\frac{\mathrm{h}}{\mathrm{h}}\right)}$, lit/ha (9)

\section{Results and Discussion}

\section{Performance evaluation of SPV module}

\section{V-I characteristics study}

The performance evaluation of the SPV module was evaluated considering V-I characteristics, power output and its conversion efficiency. From figure 6 clear that maximum solar intensity was at $12: 30 \mathrm{pm}$ $\left(682.36 \mathrm{~W} / \mathrm{m}^{2}\right)$ and minimum at 5:00 $\mathrm{pm}$ $\left(101.35 \mathrm{~W} / \mathrm{m}^{2}\right)$.

Maximum current and voltage of SPV module obtained at solar intensity $658.10 \mathrm{~W} / \mathrm{m}^{2}$ and ambient temp of $32.9^{\circ} \mathrm{C}$ is $0.61 \mathrm{~A}$ and 18.43 $\mathrm{V}$ respectively. 
Effects of ambient temperature and SPV module temperature, solar intensity on power output

According to study of SPV parameters over different atmospheric condition at maximum and minimum ambient temperature $40.1^{\circ} \mathrm{C}$ and $24.2^{\circ} \mathrm{C}$ at $13: 30 \mathrm{pm}$ and 9:00 am respectively, Maximum and minimum module temperature was $48.2^{\circ} \mathrm{C}$ and $33.39^{\circ} \mathrm{C}$ at $14: 30 \mathrm{pm}$ and 17:00 pm respectively.

Figure 7 gives the variation in solar intensity, ambient temperature and module temperature with respect to time. From figure, it has been observed that as solar intensity increases, increase in ambient temperature was found which resulted in increase in module temperature. The maximum solar intensity was found to be $\left(682.36 \mathrm{~W} / \mathrm{m}^{2}\right)$ with corresponding ambient and module temperature of about $36.6{ }^{\circ} \mathrm{C}$ and $45.33{ }^{\circ} \mathrm{C}$ at $12.30 \mathrm{pm}$, respectively.

Figure 8 gives the variation in power output, ambient temperature and module temperature with respect to time. It was observed that as ambient temperature increases, module temperature was also increased which resulted an increase in power output due to thermal losses in system. The maximum ambient temperature was found to be $40.1^{\circ} \mathrm{C}$ with corresponding module temperature of about $48.2{ }^{\circ} \mathrm{C}$ which cause decrease in power output of about 9.56 Watt at 13: $30 \mathrm{pm}$. The maximum power output was found to be 11.24 Watt at 11.30 am with corresponding ambient and module temperature of about 32.9 and $44.2{ }^{\circ} \mathrm{C}$, respectively.

Maximum and minimum solar intensity $682.36 \mathrm{~W} / \mathrm{m}^{2}$ and $101.35 \mathrm{~W} / \mathrm{m}^{2}$ recorded at temperature of $36.6^{\circ} \mathrm{C}$ and $28.1^{\circ} \mathrm{C}$ respectively. It was observed that increases in ambient temperature resulted in increase in solar intensity and vice versa. Figure 9 shows variation in solar intensity and ambient temperature with respect to time.

Effects of solar intensity on power output and efficiency of SPV Module

According to observations recorded maximum and minimum power output $11.24 \mathrm{~W}$ and 2.18 W was obtained at solar intensity $658.10 \mathrm{w} / \mathrm{m}^{2}$ and $101.35 \mathrm{~W} / \mathrm{m}^{2}$ respectively. It was observed that increase in solar intensity resulted increase in power output of SPV module and vice versa. Figure 10 shows variation in power output of SPV module against the solar intensity.

\section{Variation in power output of SPV module with respect to solar intensity}

The maximum and minimum efficiency of SPV Module was $12 \%$ and $8 \%$ at solar intensity of $433.93 \mathrm{~W} / \mathrm{m}^{2}$ and $620.73 \mathrm{~W} / \mathrm{m}^{2}$. It was resulted that Efficiency of SPV module increases as increase in ambient temperature and solar intensity and decreases as increase in panel temp. Increases beyond limit maximum efficiency of module is obtained at standard temperature $25^{\circ} \mathrm{C}$ and intensity of solar radiation $1000 \mathrm{~W} / \mathrm{m}^{2}$. Figure 11 shows variation in efficiency of SPV module with respect to solar intensity.

\section{Laboratory test of pump and nozzles}

As per Indian standard 10134:1994 the discharge of one minute from the pump at the interval of one hour for total period of 48 hours was collected in measuring jar. As per average of observations we recorded free flow of diaphragm and piston pump was $2833 \mathrm{ml}$ and $587 \mathrm{ml}$ respectively, There was very small variation in discharge seen from start to end of the test was $0.11 \%$ and $4.16 \%$, respectively as shown in figure 12 Variations occurs during endurance test was $0.11 \%$ and $4.16 \%$ respectively. 


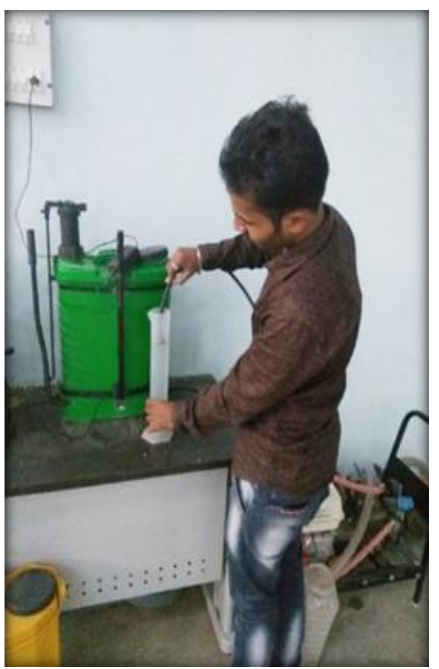

Fig1: View of pump discharge measurement

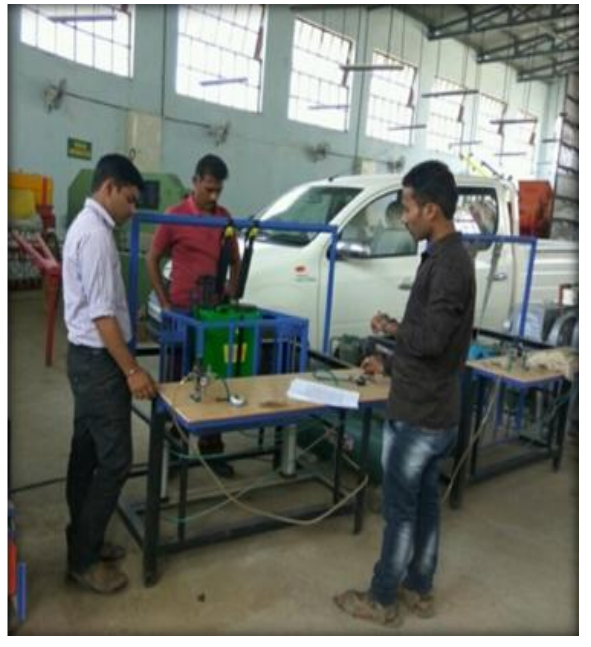

Fig3: Test setup for strap and its assembly

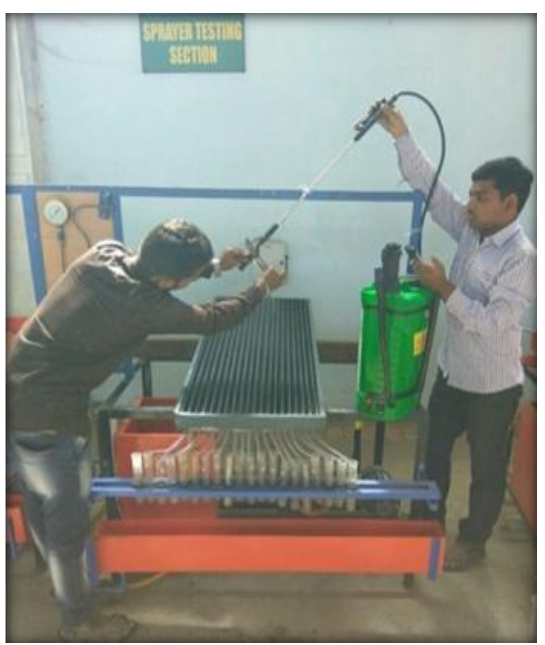

Fig2: View of spray distribution patternator test \& cone angle measurement

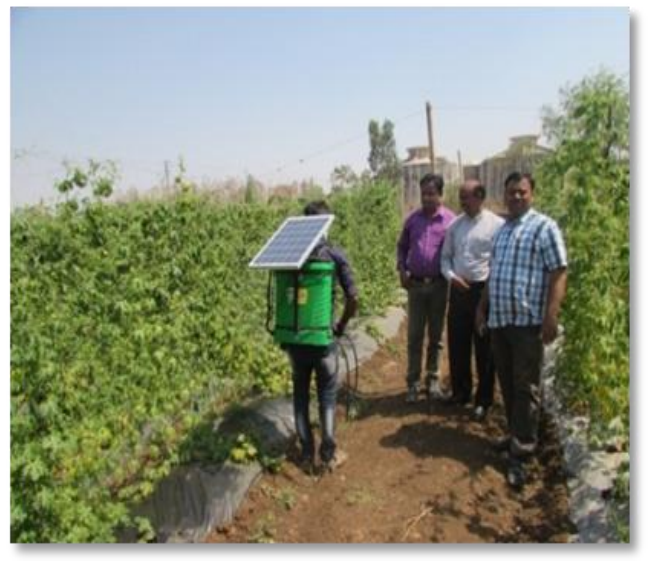

Fig4: Field Test of sprayer on Bitter gourd crop

Fig.5 Field Test of sprayer on Okra crop

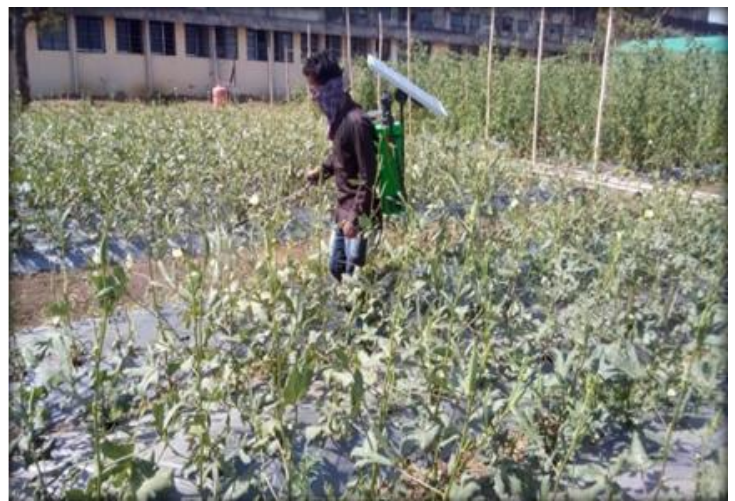




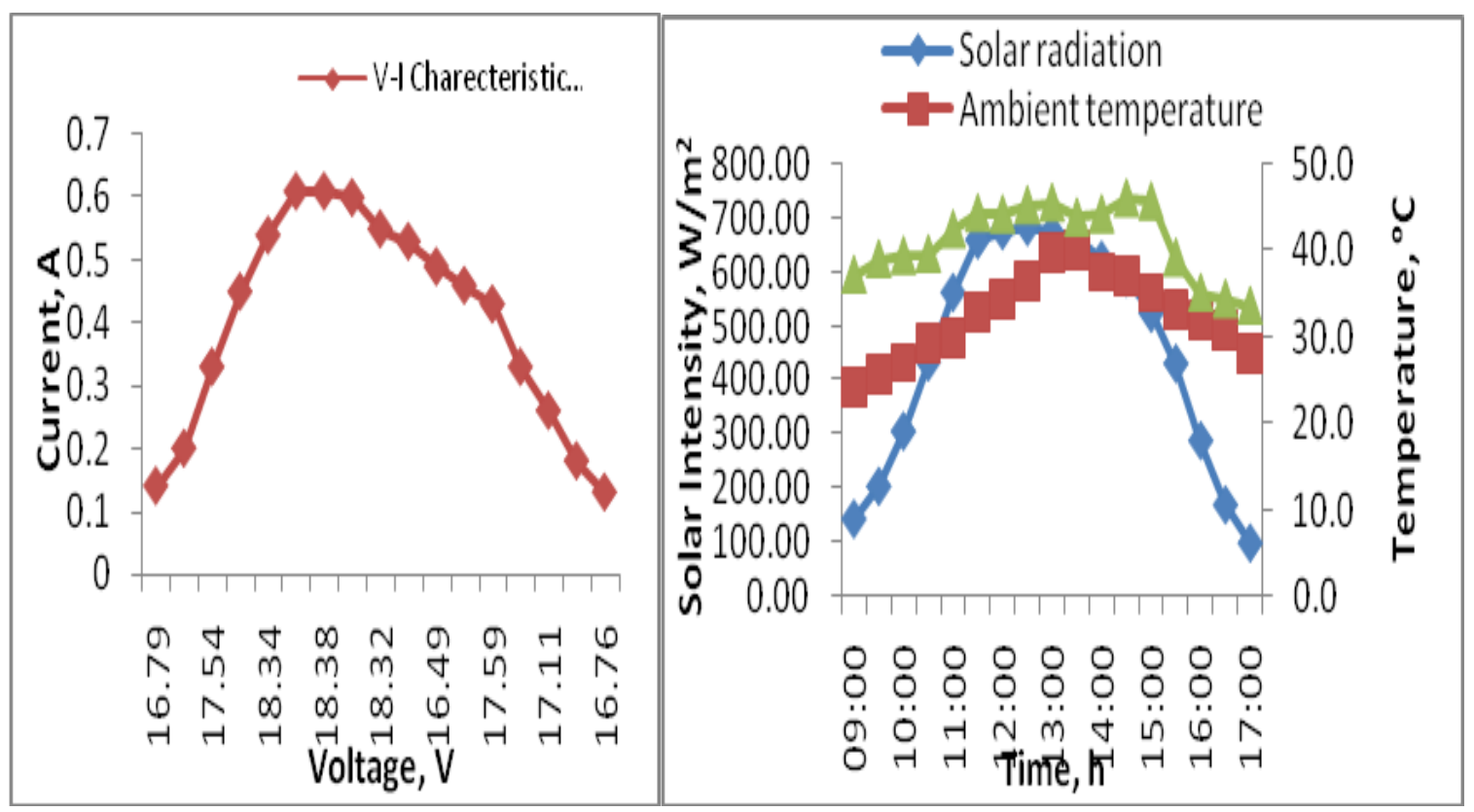

Fig6.V-I Characteristic of SPV Module. Fig 7.Variation in solar intensity, ambient Temperature and module temperature with respect to time

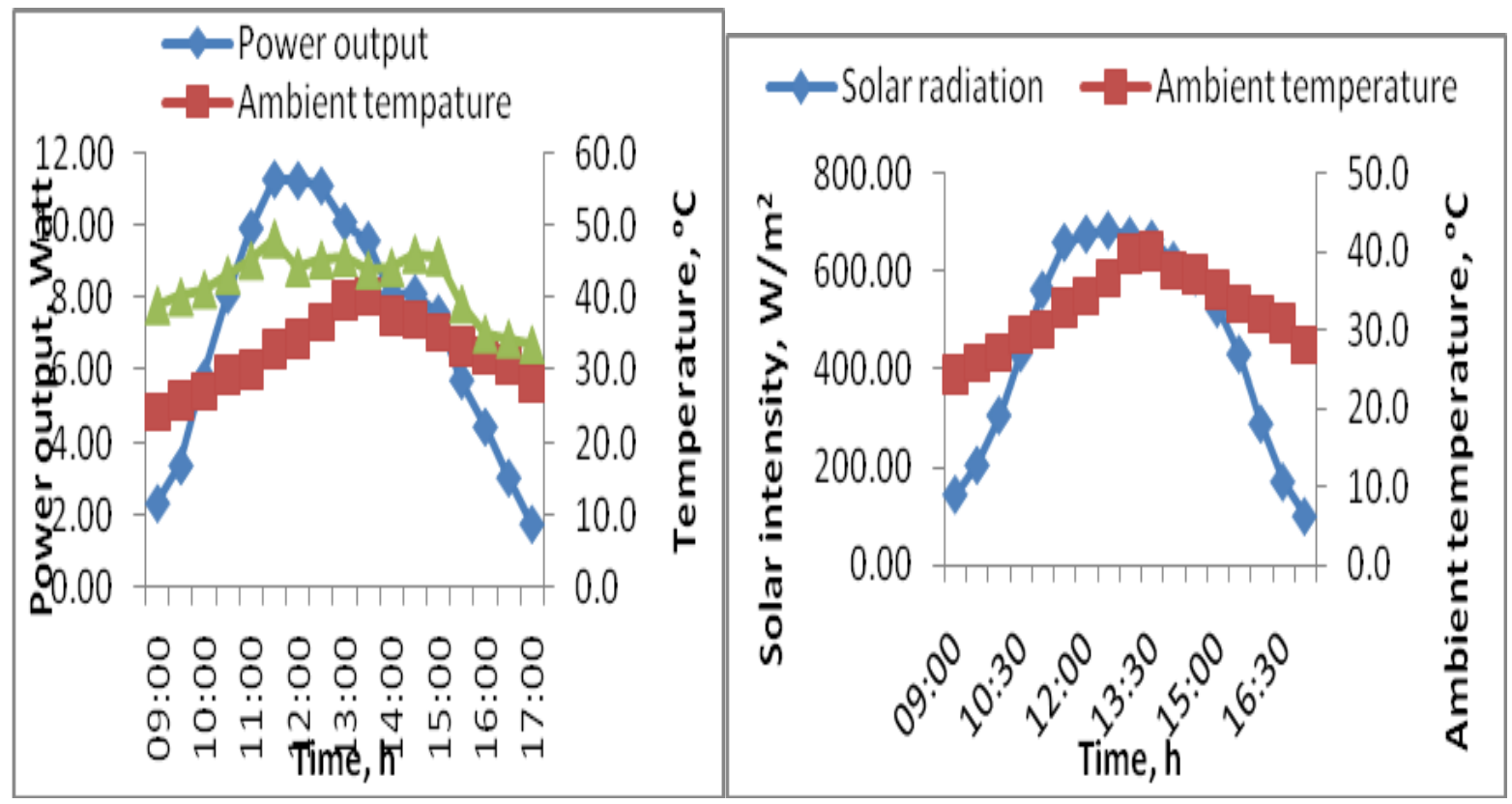

Fig 8.Variation in power output, ambient temperature and module temperature with Respect to time.
Fig9.Variation in solar intensity and ambient temperature with respect to time. 


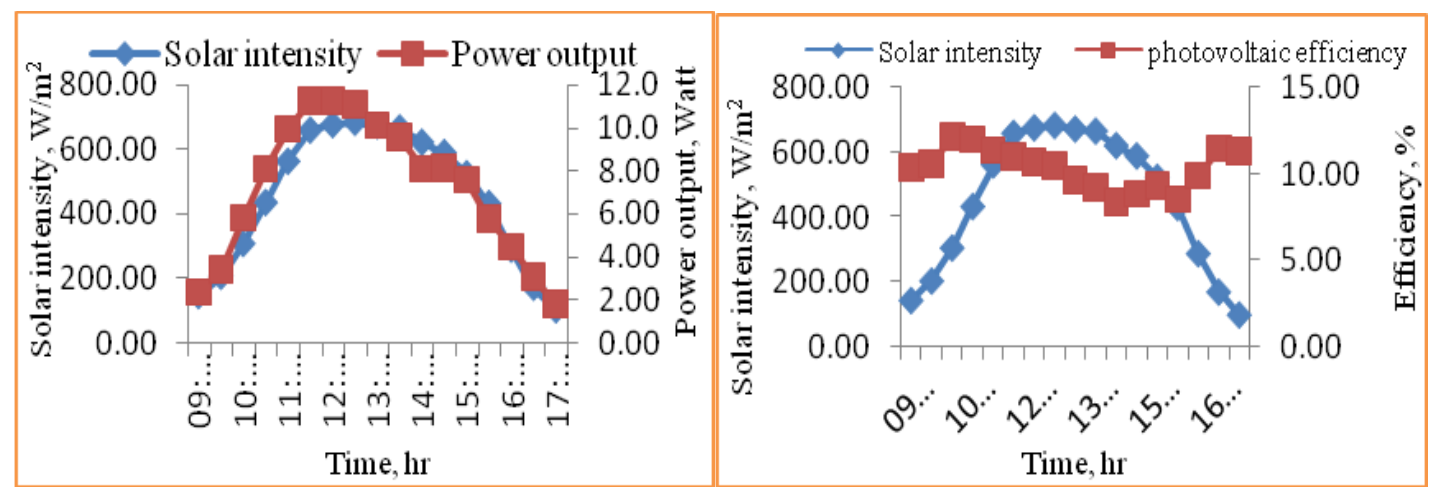

Fig.10 Variation in power output of SPV module against solar intensity Curve

Fig.11 Variation in efficiency of SPV Module against solar intensity Curve.
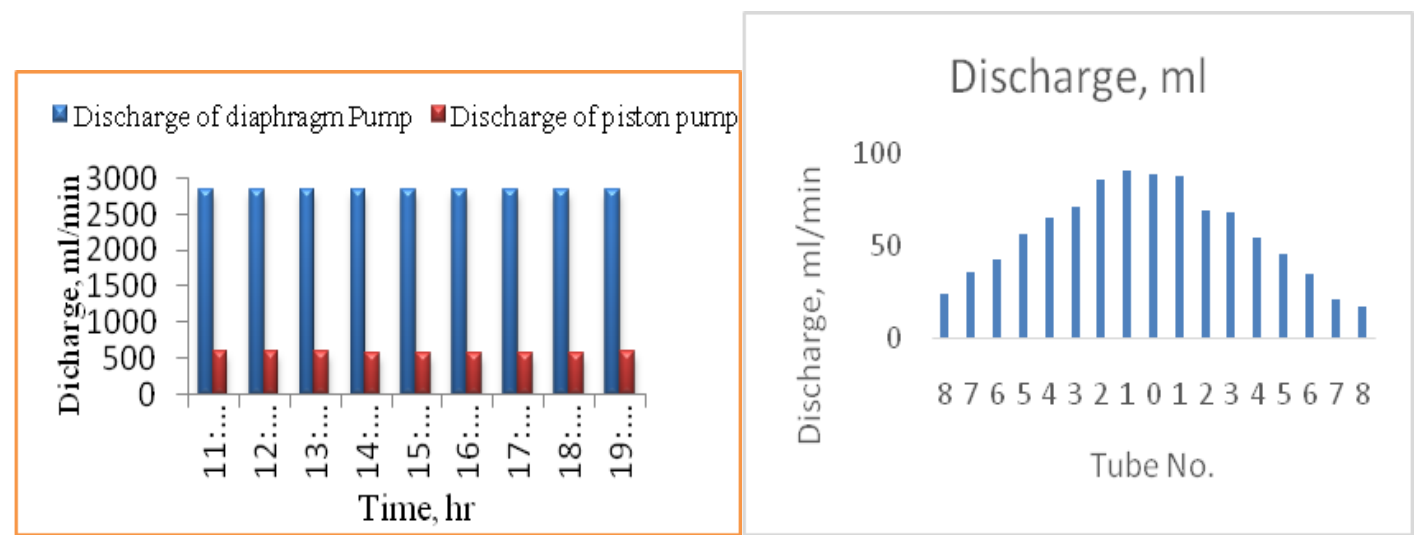

Fig.12 Variation in discharge Rate of piston pump and diaphragm pump with respect to time during pump test.

Fig.13 Variation in discharge in a tube by hollow cone nozzle .

Table.1 Comparative points between SPV, battery cum hand operated knapsack sprayer and Hand lever operated knapsack sprayer

\begin{tabular}{|l|l|c|c|}
\hline S.N. & Parameters & $\begin{array}{c}\text { SPV, battery cum hand } \\
\text { operated knapsack sprayer }\end{array}$ & $\begin{array}{c}\text { Hand lever operated } \\
\text { knapsack sprayer }\end{array}$ \\
\hline 01 & Time for Spray(h/ha) & 12.26 & 21.50 \\
\hline $\mathbf{0 2}$ & Swath width $(\mathrm{m})$ & 0.51 & 0.46 \\
\hline $\mathbf{0 3}$ & Speed of operation $(\mathrm{km} / \mathrm{h})$ & 1.80 & 1.18 \\
\hline $\mathbf{0 4}$ & Theoretical field capacity (ha/h) & 0.092 & 0.054 \\
\hline $\mathbf{0 5}$ & Actual Field Capacity (ha/h) & 0.082 & 0.044 \\
\hline $\mathbf{0 6}$ & Field Efficiency (\%) & 89.42 & 80.39 \\
\hline $\mathbf{0 7}$ & Solution required (lit/ha) & 498 & 512 \\
\hline $\mathbf{0 8}$ & Cost of Sprayer (Rs.) & 4500 & 1250 \\
\hline
\end{tabular}


Table.2 Comparison between different points in spraying of okra and bitter guard using hollow cone nozzle and twin nozzle by SPV, battery cum hand operated knapsack sprayer

\begin{tabular}{|l|l|c|c|c|c|}
\hline \multirow{2}{*}{ S.N. } & \multicolumn{1}{|c|}{ Parameters } & \multicolumn{2}{c|}{ Okra Crop } & \multicolumn{2}{c|}{ Bitter guard Crop } \\
\hline $\mathbf{1}$ & Time for Spray (h/ha) & $\begin{array}{c}\text { Hollow } \\
\text { cone nozzle }\end{array}$ & $\begin{array}{c}\text { Twin } \\
\text { nozzle }\end{array}$ & $\begin{array}{c}\text { Hollow cone } \\
\text { nozzle }\end{array}$ & Twin nozzle \\
\hline $\mathbf{2}$ & Swath width (m) & 12.19 & 10.15 & 18.32 & 15.66 \\
\hline $\mathbf{3}$ & Speed of operation (km/h) & 0.51 & 0.61 & 0.51 & 0.61 \\
\hline $\mathbf{4}$ & Theoretical field capacity (ha/h) & 0.093 & 0.111 & 0.075 & 0.090 \\
\hline $\mathbf{5}$ & Actual Field Capacity (ha/h) & 0.080 & 0.094 & 0.059 & 0.072 \\
\hline $\mathbf{6}$ & Field efficiency (\%) & 86.02 & 84.68 & 78.66 & 80.00 \\
\hline $\mathbf{7}$ & Solution required (lit/ha) & 498 & 520 & 823 & 815 \\
\hline
\end{tabular}

Table.3Observations of parameters of SPV module in different atmospheric condition

\begin{tabular}{|c|c|c|c|c|c|c|c|c|c|}
\hline \multirow[t]{2}{*}{ S.N. } & \multirow{2}{*}{$\begin{array}{c}\text { Time, } \\
\text { h }\end{array}$} & \multirow{2}{*}{$\begin{array}{c}\text { Ambient } \\
\text { temp., } \\
{ }^{\circ} \mathrm{C}\end{array}$} & \multirow{2}{*}{$\begin{array}{c}\mathrm{I}, \\
\mathrm{W} / \mathrm{m} 2\end{array}$} & \multirow{2}{*}{$\begin{array}{l}\mathrm{Sw}, \\
\mathrm{m} / \mathrm{s}\end{array}$} & \multicolumn{3}{|c|}{ SPV Panel } & \multirow{2}{*}{$\begin{array}{c}\text { Power, } \\
\text { W }\end{array}$} & \multirow[t]{2}{*}{$\eta, \%$} \\
\hline & & & & & $\begin{array}{c}\text { Current, } \\
\text { A }\end{array}$ & $\begin{array}{c}\text { Voltage, } \\
\text { V }\end{array}$ & $\begin{array}{l}\text { Module } \\
\text { temp., }{ }^{\circ} \mathrm{C}\end{array}$ & & \\
\hline 1 & 09:00 & 24.2 & 145.56 & 1.11 & 0.14 & 16.79 & 39.02 & 2.35 & 0.10 \\
\hline 2 & $09: 30$ & 25.7 & 205.56 & 0.88 & 0.2 & 16.93 & 40.2 & 3.39 & 0.11 \\
\hline 3 & $10: 00$ & 27.1 & 306.69 & 0.92 & 0.33 & 17.54 & 41.2 & 5.79 & 0.12 \\
\hline 4 & $10: 30$ & 29.4 & 433.93 & 1.60 & 0.45 & 17.95 & 43.2 & 8.08 & 0.12 \\
\hline 5 & $11: 00$ & 30.0 & 561.47 & 1.60 & 0.54 & 18.34 & 45.2 & 9.90 & 0.11 \\
\hline 6 & $11: 30$ & 32.9 & 658.10 & 1.10 & 0.61 & 18.43 & 48.2 & 11.24 & 0.11 \\
\hline 7 & $12: 00$ & 34.4 & 675.07 & 2.30 & 0.61 & 18.38 & 44.24 & 11.21 & 0.11 \\
\hline 8 & $12: 30$ & 36.6 & 682.36 & 1.00 & 0.6 & 18.45 & 45.33 & 11.07 & 0.10 \\
\hline 9 & $13: 00$ & 39.7 & 671.53 & 0.80 & 0.55 & 18.32 & 45.61 & 10.08 & 0.10 \\
\hline 10 & $13: 30$ & 40.1 & 665.04 & 0.20 & 0.53 & 18.04 & 43.89 & 9.56 & 0.09 \\
\hline 11 & $14: 00$ & 37.6 & 620.73 & 0.40 & 0.49 & 16.49 & 44.26 & 8.08 & 0.08 \\
\hline 12 & $14: 30$ & 37.0 & 588.80 & 1.20 & 0.46 & 17.62 & 46.09 & 8.11 & 0.09 \\
\hline 13 & $15: 00$ & 35.2 & 523.45 & 1.20 & 0.43 & 17.59 & 45.76 & 7.56 & 0.09 \\
\hline 14 & $15: 30$ & 33.3 & 431.06 & 1.10 & 0.33 & 17.36 & 39.21 & 5.73 & 0.09 \\
\hline 15 & $16: 00$ & 32.0 & 289.43 & 0.90 & 0.26 & 17.11 & 35.11 & 4.45 & 0.10 \\
\hline 16 & $16: 30$ & 30.8 & 171.41 & 0.60 & 0.18 & 16.96 & 34.41 & 3.05 & 0.11 \\
\hline 17 & $17: 00$ & 28.1 & 101.35 & 1.10 & 0.11 & 16.18 & 33.59 & 1.78 & 0.11 \\
\hline Avg. & & & 454.80 & 1.06 & 0.40 & 17.56 & & 7.14 & 0.10 \\
\hline
\end{tabular}


Table.4 Observation for field efficiency of SPV, battery cum hand operated knapsack sprayer

\begin{tabular}{|c|c|c|c|c|c|c|c|c|}
\hline \multirow{2}{*}{$\begin{array}{l}\text { S. } \\
\text { N. }\end{array}$} & Length & Time & Speed & \multirow{2}{*}{$\begin{array}{c}\text { Width of } \\
\text { spraying(m) }\end{array}$} & T.F.C & E.F.C. & \multirow{2}{*}{$\begin{array}{l}\text { Field efficiency } \\
(\%)\end{array}$} & \multirow{2}{*}{$\begin{array}{c}\text { Avg. field } \\
\text { efficiency }(\%)\end{array}$} \\
\hline & (m) & $(\mathrm{Sec})$ & (Km/hr.) & & (ha/hr.) & (ha/hr.) & & \\
\hline 1 & 15 & 29 & 1.86 & 0.50 & 0.093 & 0.080 & 86.11 & \\
\hline 2 & 15 & 31 & 1.74 & 0.52 & 0.091 & 0.082 & 90.06 & 89.42 \\
\hline 3 & 15 & 30 & 1.80 & 0.51 & 0.092 & 0.085 & 92.10 & \\
\hline
\end{tabular}

Table.5 Observation for field efficiency of hand operated knapsack sprayer

\begin{tabular}{|c|c|c|c|c|c|c|c|c|}
\hline \multirow{2}{*}{$\begin{array}{l}\text { S. } \\
\text { N. }\end{array}$} & Length & Time & Speed & \multirow{2}{*}{$\begin{array}{c}\text { Width of } \\
\text { spraying(m) }\end{array}$} & T.F.C & E.F.C. & \multirow{2}{*}{$\begin{array}{c}\text { Field } \\
\text { efficiency }(\%)\end{array}$} & \multirow{2}{*}{$\begin{array}{c}\text { Avg. field } \\
\text { efficiency }(\%)\end{array}$} \\
\hline & (m) & $(\mathrm{Sec})$ & $(\mathrm{Km} / \mathrm{hr})$. & & (ha/hr.) & (ha/hr.) & & \\
\hline 1 & 15 & 44 & 1.23 & 0.46 & 0.056 & 0.045 & 79.20 & \\
\hline 2 & 15 & 48 & 1.13 & 0.48 & 0.054 & 0.043 & 80.37 & 80.39 \\
\hline 3 & 15 & 46 & 1.17 & 0.45 & 0.053 & 0.043 & 81.59 & \\
\hline
\end{tabular}

Table.6 Test by hollow cone nozzle and twin nozzle (working pressure: 300kpa)

\begin{tabular}{|c|c|c|c|c|c|c|c|c|c|c|c|}
\hline \multirow{2}{*}{\multicolumn{3}{|c|}{ Size of Test Plot $31 \times 15 \mathrm{~m}^{2}$}} & \multicolumn{5}{|c|}{ Crop-Okra } & \multirow{2}{*}{\multicolumn{4}{|c|}{ Age of crop - 15 Days }} \\
\hline & & & \multicolumn{5}{|c|}{$\begin{array}{c}\text { Insecticides - Trizophos + Delta methylene } \\
\text { (for White fly) }\end{array}$} & & & & \\
\hline \multirow[t]{2}{*}{ Replication } & \multicolumn{2}{|c|}{$\begin{array}{c}\text { Discharge } \\
\text { volume, lit (a) }\end{array}$} & \multirow[t]{2}{*}{$\begin{array}{l}\text { Area of } \\
\text { plot, } m^{2}\end{array}$} & \multicolumn{2}{|c|}{ Time, s (b) } & \multicolumn{2}{|c|}{$\begin{array}{l}\text { Discharge rate, } \\
\text { lit/s }(\mathrm{a} / \mathrm{b})\end{array}$} & \multicolumn{2}{|c|}{ Area rate $\left(\mathrm{m}^{2} / \mathrm{s}\right)$} & \multicolumn{2}{|c|}{$\begin{array}{c}\text { Application rate, } \\
\text { lit/ha }\end{array}$} \\
\hline & $\mathrm{V}_{1}$ & $\mathrm{~V}_{2}$ & & $\mathrm{~T}_{1}$ & $\mathrm{~T}_{2}$ & $\mathrm{Q}_{1}$ & $\mathrm{Q}_{2}$ & $\mathrm{~A}_{1}$ & $\mathrm{~A}_{2}$ & $\begin{array}{c}\text { Hollow } \\
\text { cone } \\
\text { nozzle }\end{array}$ & $\begin{array}{c}\text { Twin } \\
\text { nozzle }\end{array}$ \\
\hline 1 & 23.50 & 24.20 & \multirow{3}{*}{465} & 2088 & 1692 & 0.0113 & 0.0143 & 0.223 & 0.0275 & 505.38 & 520.43 \\
\hline 2 & 22.90 & 24.35 & & 2052 & 1721 & 0.0112 & 0,0141 & 0.227 & 0.0270 & 492.47 & 523.66 \\
\hline 3 & 23.00 & 23.90 & & 1980 & 1685 & 0.0116 & 0.0142 & 0.235 & 0.0276 & 494.62 & 513.98 \\
\hline Avg. & 23.13 & 24.15 & & 2040 & 1699. & 0.0114 & 0.0142 & 0.228 & 0.0274 & 497.49 & 519.36 \\
\hline
\end{tabular}

Table.7 Test by hollow cone nozzle and twin nozzle

\begin{tabular}{|c|c|c|c|c|c|c|c|c|c|c|c|}
\hline \multicolumn{3}{|c|}{ Size of Test Plot $31 \times 15 \mathrm{~m}^{2}$} & \multicolumn{5}{|c|}{ Crop - Bitter guard } & \multicolumn{4}{|c|}{ Age of crop - 30days } \\
\hline \multirow{3}{*}{ Replication } & & & \multicolumn{5}{|c|}{$\begin{array}{l}\text { Fungicides }- \text { Trizophos }+ \text { Delta } \\
\text { methylene }+\lambda \text { cycothine (for fruit borer) }\end{array}$} & & & & \\
\hline & \multicolumn{2}{|c|}{$\begin{array}{c}\text { Discharge } \\
\text { volume, lit (a) }\end{array}$} & \multirow{2}{*}{$\begin{array}{c}\text { Area of } \\
\text { plot, } \\
\mathrm{m}^{2}\end{array}$} & \multicolumn{2}{|c|}{ Time, s (b) } & \multicolumn{2}{|c|}{$\begin{array}{l}\text { Discharge rate, } \\
\text { lit/s }(\mathrm{a} / \mathrm{b})\end{array}$} & \multicolumn{2}{|c|}{$\begin{array}{l}\text { Area rate } \\
\left(\mathrm{m}^{2} / \mathrm{s}\right)\end{array}$} & \multicolumn{2}{|c|}{$\begin{array}{l}\text { Application rate, } \\
\text { lit/ha }\end{array}$} \\
\hline & $\mathrm{Q}_{1}$ & $\mathrm{Q}_{2}$ & & $\mathrm{~T}_{1}$ & $\mathrm{~T}_{2}$ & $\mathrm{Q}_{1}$ & $\mathrm{Q}_{2}$ & $\mathrm{~A}_{1}$ & $\mathrm{~A}_{2}$ & $\begin{array}{l}\text { Hollow } \\
\text { cone } \\
\text { nozzle }\end{array}$ & $\begin{array}{c}\text { Twin } \\
\text { nozzle }\end{array}$ \\
\hline 1 & 38.50 & 38.00 & \multirow{3}{*}{465} & 2940 & 2540 & 0.0131 & 0.0150 & 0.158 & 0.183 & 827.96 & 817.20 \\
\hline 2 & 38.20 & 37.50 & & 3120 & 2674 & 0.0122 & 0,0140 & 0.149 & 0.174 & 821.51 & 806.45 \\
\hline 3 & 38.00 & 38.20 & & 3140 & 2650 & 0.0121 & 0.0144 & 0.148 & 0.175 & 817.20 & 821.51 \\
\hline Avg. & 38.23 & 37.90 & & 3067 & 2621 & 0.0125 & 0.0144 & 0.152 & 0.177 & 822.22 & 815.05 \\
\hline
\end{tabular}


Table.8 Specification of SPV, battery cum hand operated knapsack sprayer

\begin{tabular}{|c|c|c|c|}
\hline Sr. No. & Components & Specifications & Materials \\
\hline 01 & $\begin{array}{l}\text { Solar photovoltaic module } \\
\text { No of modules } \\
\text { Dimension } \\
\text { No of solar cells } \\
\text { Short circuit current (Isc) } \\
\text { Open circuit voltage } \\
\text { Maximum power } \\
\text { Weight }\end{array}$ & $\begin{array}{l}1 \\
\text { Rectangular } 48.5 \times 32 \\
\mathrm{~cm} 2 \\
36 \\
1.14 \mathrm{~A} \\
22.08 \mathrm{~V} \\
20 \mathrm{Watt}\end{array}$ & Silicon Cell \\
\hline 02 & Charge control unit Capacity & $5 \mathrm{~A}$ & \\
\hline 03 & $\begin{array}{l}\text { Battery } \\
\text { Type } \\
\text { Voltage } \\
\text { Capacity }\end{array}$ & $\begin{array}{l}\text { Sealed Lead Acid Battery } \\
\text { 12V8Ah }\end{array}$ & Lead Acid \\
\hline 04 & $\begin{array}{l}\text { Pump } \\
\text { Type of pump } \\
\text { Discharge } \\
\text { Pressure }\end{array}$ & $\begin{array}{l}\text { Diaphragm pump \& } \\
\text { piston pump } \\
\text { lit/min } \\
80 \mathrm{PSI}\end{array}$ & \\
\hline 05 & $\begin{array}{l}\text { Hose pipe } \\
\text { Length } \\
\text { Diameter } \\
\text { Pressure bearing capacity }\end{array}$ & $\begin{array}{l}130 \mathrm{~cm} \\
10 \mathrm{~mm} \\
300 \mathrm{kpa}\end{array}$ & Rubber \\
\hline 06 & Cut-off device Type & Trigger & Plastic \\
\hline 07 & $\begin{array}{l}\text { Spray lance } \\
\text { Type } \\
\text { Length } \\
\text { Diameter }\end{array}$ & $\begin{array}{l}\text { Straight type } \\
550 \mathrm{~mm}-900 \mathrm{~mm} \\
6 \mathrm{~mm}\end{array}$ & Stainless steel \\
\hline 08 & Type of nozzle & $\begin{array}{l}\text { Hollow cone nozzle } \\
\text { Twin nozzle }\end{array}$ & Plastic \\
\hline 09 & $\begin{array}{l}\text { Frame } \\
\text { Weight }\end{array}$ & $1.6 \mathrm{~kg}$ & Mild steel \\
\hline 10 & $\begin{array}{l}\text { Tank } \\
\text { Capacity } \\
\text { Height } \\
\text { Width } \\
\text { Weight (empty tank) }\end{array}$ & $\begin{array}{l}16 \mathrm{lit} \\
400 \mathrm{~mm} \\
300 \mathrm{~mm} \\
4.65 \mathrm{~kg}\end{array}$ & Plastic \\
\hline 11 & $\begin{array}{l}\text { Strap } \\
\text { Length } \\
\text { Thickness } \\
\text { Width }\end{array}$ & $\begin{array}{l}800 \mathrm{~mm} \\
20 \mathrm{~mm} \\
40 \mathrm{~mm}\end{array}$ & $\begin{array}{l}\text { Plastic coated } \\
\text { fabric, rexin etc. }\end{array}$ \\
\hline 07 & Pressure gauge Range & $700 \mathrm{kpa}$ & \\
\hline 08 & Weight of sprayer without liquid & $6.45 \mathrm{~kg}$ & \\
\hline 09 & Weight of sprayer with liquid & $22.45 \mathrm{~kg}$ & \\
\hline
\end{tabular}


The discharge was recorded for $6 \mathrm{~h}$ interval at $300 \mathrm{kPa}$ as per standard. Average discharge obtained $1380 \mathrm{ml} / \mathrm{min}$ from hollow cone nozzle and $1455 \mathrm{ml} / \mathrm{min}$ from twin nozzle. Variation in discharge was $0.73 \%$ and $2.1 \%$ respectively. The average spray angle of hollow cone nozzle and twin nozzle were $74.65^{\circ}$ and $91.91^{\circ}$, respectively and variation in spray angle were $1.49 \%$ and $1.66 \%$, respectively. There is no leakage or breakdown is observed in the pump and nozzles during Test.

\section{Spray distribution patternator test}

As per Indian Standard 10134:1994patternator test was carried over patternator test rig of 16 channel and measured discharge of one minute in the 16 channels. It is found that in hollow cone nozzle discharge is more in center and decreases from center to right and left. In twin nozzle, the overlap of spray angle occurred in center so discharge obtained in center is more than right and left side of the channel. The variation in discharge by hollow cone nozzle is represented in figure 13.

The performance and evaluation trial of Sprayer has been carried out as per testing procedure mentioned given in Indian Standard. The width of spraying affects effective field capacity of sprayer.

The average observed width was $0.51 \mathrm{~m}$ at operation speed of $1.82 \mathrm{~km} / \mathrm{h}$. It was observed that the working on these speeds was convenient for field operations without any obstacle. The theoretical and actual field capacity of the sprayer for insecticides application in the field was found to be 0.093 $\mathrm{ha} / \mathrm{h}$ and $0.082 \mathrm{ha} / \mathrm{h}$. The field capacity and field efficiency of the sprayer depends upon size of plot, swath width, speed and skill of operator. The field efficiency of the Sprayer was found to be $88.93 \%$. The average application rate of the Solar Charge, Battery cum Hand Operated Knapsack Sprayer was 502.15 lit/ha.

This research work was undertaken for development of SPV, battery cum hand operated knapsack sprayer for field crop spraying. Following conclusions are made from the present research study.

Maximum short circuit current $\left(\mathrm{I}_{\mathrm{sc}}\right)$ power $(\mathrm{W})$ developed by the solar cells is found at 11:30 am.

Current and power produced by solar cells depends upon solar intensity.

The relation between the $I_{s c}$ and $V_{s c}$ represents that the $\mathrm{V}_{\mathrm{sc}}$ always approximately remains constant and $\mathrm{I}_{\mathrm{sc}}$ vary according to increase in ambient temperature and it is maximum at noon.

The V-I characteristic of the solar PV module changes as the solar intensity increases and Isc also increases as the solar intensity increases.

In Laboratory during discharge test there is little variation in discharge occurs. Average discharge obtained from the diaphragm pump and piston pump was 2832 and $587 \mathrm{ml} / \mathrm{min}$.

In Endurance test of diaphragm pump, piston pump and nozzles no leakage or breakage occurs in the components.

In test of spray pattern, the spray of nozzle was nearly uniform and spray angle for hollow cone nozzle and twin nozzle were $74.65^{\circ}$ and $91.91^{\circ}$ respectively.

In test of components of sprayer such as operating lever, handle, hose and hose connection, strap and its assembly there is no breakage occurs in components.

The field trial data represented that time require to spray 1 ha field by SPV, battery cum hand operated knapsack sprayer is 1.75times less than time required to spray by Hand lever operated knapsack sprayer, feels less fatigue to operator. Field capacity of SPV, battery cum hand operated knapsack sprayer and Hand operated knapsack sprayer were obtained as $0.082 \mathrm{ha} / \mathrm{h}$ and $0.044 \mathrm{ha} / \mathrm{h}$, respectively, that 
means SPV, battery cum hand operated knapsack sprayer has2times greater field capacity than Hand operated knapsack sprayer (Table 1-8).

Speed of operation of SPV, battery cum hand operated knapsack sprayer and Hand operated knapsack sprayer were observed as $1.80 \mathrm{~km} / \mathrm{h}$ and $1.18 \mathrm{~km} / \mathrm{h}$ respectively, that means $\mathrm{SPV}$, battery cum hand operated knapsack sprayer has operating velocity 1.52 times as compared to Hand operated knapsack sprayer because hand operated sprayer requires more manual power due which speed of spraying was reduced.

\section{References}

Agrawal L. (2005). Testing of SPV powered boom sprayer, unpublished B-Tech project report submitted to CAET, Dr. PDKV, Akola

Anonymous (1994). Indian standard code IS: 10134 for guide methods of test for manually operated sprayers (FAD21: Farm implements and machinery) at http://www.standerdsbis.in.

Anonymous (1995). Indian standard code IS: 3906 for guide methods of test for crop protection equipment hand operated knapsack sprayer piston type at http://www.standerdsbis.in.

Anonymous (2010). Indian standard code IS: 12762 for guide methods of test for measurement of photovoltaic currentvoltage characteristics. http://www. standerdsbis.in.

Brinkworth, B. J. (1975): Solar Energy for Man. N. Y., John Wiley and Sons Publ.
Cini, C. (1992): Experiment on the Effect of Drift of Weed Spray Boom. Georgofili, Vol. (38): 61- 65.

Irshad Ali and T. P. Ojha (1968): Spray Intensity Distribution Pattern of Fan Type Sprayer Nozzle. Journal of Agril. Engg. 30:22-25.

Karale, D.S., Kankal, U.S., Khambalkar, V. P. and Gajakos, A. V. (2014). Performance evaluation of self-propelled boom sprayer. IJAE Agri.Engg.7 (1):137-141.

Langerakers (1999): Effect of vertical sprayer from Movement on the Uniformity of spring Distribution, Journal of Agril. Engg. Vol. 72:90-95

Mali, P. J. and Ahirl, Y. G. (2016): Farmer friendly Solar Operated Spray Pump: IRJET Vol: 03

Mathew, G. A. (1979): Pesticides Application Methods, Longman Group Ltd., London.

Parker, B. F. (1991): Solar energy in agriculture, Elsevier Science Publishers B. V., The Netherlands.

Patil A. P. and Chavan S. V. (2014): Performance evaluation of Solar Operated Knapsack Sprayer. Agril. India Today Vol.38 (3)

Rai, G. D. (1997): Solar energy utilization, khanna Pub. New Delhi.

Rajesh, R., and Kingsley (2016): Design and Fabrication of Solar Pesticide Sprayer. IJIRSET, Vol.5 (8)

Salyani, M. (1993): A Device and Method for sprayer calibration. Applied Engg. In Agril. 9(1): 29-32.

Smith, G. (1971) Energy for world agriculture, F.A.O. Rome.

Thereja, B. L. (1995): Electrical technology, S. Chand and Co. Ltd. New Delhi.

\section{How to cite this article:}

Shubham R. Zilpilwar, Surendra R. Kalbande, Manisha V. Gahane and Neha Daharwal. 2018. Field and Laboratory Studies of Solarcum Hand Operated Hybrid Knapsack Sprayer. Int.J.Curr.Microbiol.App.Sci. 7(03): 2932-2945. doi: https://doi.org/10.20546/ijcmas.2018.703.339 